\title{
Ethephon Hastens Maturity of Passionfruit Grown as an Annual in a Temperate Zone
}

\author{
W.A. Dozier, Jr. ${ }^{1}$, R. Rodriguez-Kabana ${ }^{2}$, A.W. Caylor ${ }^{3}$, \\ D.G. Himelrick ${ }^{4}$, N.R. McDaniel ${ }^{5}$, and J.A. McGuire ${ }^{6}$ \\ Horticulture Department, Alabama Agricultural Experiment Station, \\ Auburn University, AL 36849
}

Additional index words. Passiflora edulis, P. edulis f. flavicarpa, 2-chloroethylphosphonic acid, fruit ripening

\begin{abstract}
The yellow passionfruit (Passiflora edulis $f$ flavicarpa Degener), a perennial vine grown in the tropics and subtropics, was successfully grown as an annual crop in a temperate zone. Fruit maturity was hastened by ethephon treatments to allow harvest before the mean date of the first killing frost. Maturity was advanced in a linear manner with application rates of 150,300 , and $600 \mathrm{ppm}$ ethephon. Total yield was not affected by ethephon treatment; however, cull fruit producing no juice increased with increasing rates of ethephon, thereby reducing marketable yields. Soluble solids and ascorbic acid contents of the juice were not affected by ethephon treatment. Purple passionfruit (Passiflora edulis Sims) did not produce blossoms.
\end{abstract}

Passionfruit is a perennial, vigorous, climbing woody vine that is native to tropical America, but is cultivated throughout the tropics and subtropics (McGregor, 1976; Morton, 1987). There are $\approx 300$ species of Passiflora; however, only four species, $P$. edulis Sims, $P$. quadrangularis L., $P$. ligularis, and $P$. mollissima, are cultivated for food. The most important species, P. edulis, has two important recognized forms. The purple passionfruit, $P$. edulis, is the normal form and the yellow passionfruit, $P$. edulis $f$. flavicarpa, is presumed to have originated as a mutation from the purple passionfruit.

The purple passionfruit is the one more resistant to cold injury and has superior fruit flavor (Morton, 1987). The yellow passionfruit is larger $(80 \mathrm{~g})$ than the purple passionfruit (35 g) (Casimir et al., 1981). The yellow passionfruit vine grows rapidly, produces fruit 1 to 3 years after planting, and produces a yield about five times greater than the purple passionfruit (Martin, 1984; Morton, 1987; Williams et al., 1980). It produces fruit throughout the year in India, with peak production occurring from August to December and March to May, and from June through January in Hawaii, with peak production July through August and October through November (Morton, 1987). Fruit of the yellow passionfruit matures in $\approx 70$ days, whereas

Received for publication 30 Apr. 1990. Alabama Agricultural Experiment Station Journal Series no. 11-902552P. The cost of publishing this paper was defrayed in part by the payment of page charges. Under postal regulations, this paper therefore must be hereby marked advertisement solely to indicate this fact.

${ }^{1}$ Professor, Dept. of Horticulture.

${ }^{2}$ Professor, Dept. of Plant Pathology.

${ }^{3}$ Research Specialist, Dept. of Horticulture.

${ }^{4}$ Associate Professor, Dept. of Horticulture.

${ }^{5}$ Assistant Superintendent, Gulf Coast Substation.

${ }^{6}$ Professor and Head, Dept. of Research Data Analysis. fruit of the purple passionfruit matures in $\approx 80$ to 85 days after pollination (Casimir et al., 1981).

Plant and fruit responses to ethylene have been reviewed by Pratt and Goeschl (1969). Responses to ethylene include increased respiration of fruit, and hastened fruit maturity and leaf senescence. Ethephon (2-chloroethyl-phosphoric acid) applied as foliar sprays liberates ethylene after it enters the plant tissue, thus accounting for the ethylene-type responses obtained with ethephon (Warner and Leopold, 1969). Ethephon treatments have been shown to hasten leaf senescence (Ketchie and Williams, 1970) and ripening of fruits (Buckovac et al., 1969; Edgerton and Blanpied, 1968; Russo et al., 1968) and vegetables (Robinson et al., 1968; Sims et al., 1970). This study was conducted to determine if the two forms of $P$. edulis could be successfully grown in a temperate zone as an annual crop by using ethephon to ripen fruit before frosts.

Seeds of the yellow and purple passionfruit were sown in the greenhouse on 15 Jan. 1988 with uniform emergence occurring within 2 weeks. Individual seedlings were transplanted into $25-\mathrm{cm}\left(542-\mathrm{cm}^{3}\right)$-square pots filled with an artificial soil medium (Premix, Premier Brands of Canada, Riviere Du Loup, Quebec, Canada) and fertilized 3 weeks after seed germination with $200 \mathrm{ppm} \mathrm{N}$ (using 20N-8.4P-16.4K) from a soluble fertilizer. The seedlings were set in the field at the Gulf Coast Substation, Fairhope, Ala., at a 1.8 $\times 3.0-\mathrm{m}$ spacing on 19 Apr., 80 days after seed germination. A two-wire vertical trellis was used to support the plants. The wires were $0.9 \mathrm{~m}$ and $1.8 \mathrm{~m}$ from the ground, with the posts spaced $3.6 \mathrm{~m}$ apart. The plants were grown with trickle irrigation using one 3.85 liter.hr ${ }^{-1}$ emitter per plant. Ethephon treatments were applied to runoff with a backpack-type sprayer on 27 Oct.

Two species of passionfruit, yellow and purple, were used, each in a strip crossing four blocks. Within each block, ethepbon treatments of $\mathrm{O}, 150,300$, and $600 \mathrm{ppm}$ were applied, randomized in each species. Two plants were included in each plot. This arrangement resulted in a split plot with species as the whole plots stripped across blocks and ethephon treatments as subplots. Vines of the yellow passionfruit were well-developed and covered the trellis by late August. A few scattered blossoms were observed in late August, with heavy bloom commencing in mid- to late September; flower production continued until the first killing frost. Pollination was accomplished by natural insect populations. The purple passionfruit vines were not as vigorous as the yellow passionfruit vines and did not produce blossoms. Thus, data were collected only from the yellow passionfruit, resulting in a randomized complete-block design for yellow passionfruit only, with four ethephon levels. Linear, quadratic, and cubic components of the treatment effects were computed and appropriate tests of treatment effects were made at $P \approx 0.05$.

The fruit were harvested when they had turned yellow (from the plant, or from the ground, if they had dropped) on 16, 22, and 28 Nov. and 6 and 12 Dec. Total fruit weight and number of fruit per harvest date were recorded. Each fruit was cut to evaluate the development of the pulpy juice sacs. Those fruit not containing developed juice sacs were considered culls. The marketable yield was obtained by subtracting the weight of the cull fruit from the total fruit yield. The pulpy interior was removed from 20 mature fruit of each treatment replicate and the juice removed by squeezing the pulp through cheese cloth. The percent soluble solids concentration (SSC) of the juice was determined with a hand refractometer. The ascorbic acid content of the juice was determined by the method of Rymal (1983). Juice color was determined by use of a Hunter Color Difference Meter D25 D2 (Hunter Laboratory, Fairfax, Vs.).

The leaves on the ethephon-treated plants began to senesce $\approx 1$ week after treatment. Vines treated with 300 and 600 ppm ethephon did not produce any blossoms after treatment, whereas the controls and those treated with $150 \mathrm{ppm}$ continued to grow and produce blossoms and set fruit.

Fruit maturity was enhanced by all ethephon treatments (Table 1). On the first harvest date (16 Nov.), all levels of ethephon enhanced the percent yield of mature fruit over the next lower level, resulting in an overall linear response $(P \approx 0.01)$. However, the differences between higher levels were not as great as between lower levels, producing a quadratic response $(P \approx 0.05)$. Most of the fruit on the treated vines (150, $66 \%$; 300, 82\% ; and $600 \mathrm{ppm}, 92 \%$ ) shrivelled and turned yellow by the second harvest date (22 Nov.), which was before the average first killing frost date (25 Nov.). The fruit on the control vines did not shrivel before harvest. A large percentage $(66 \%)$ of the fruit from the control vines was harvested after 22 Nov., with $47 \%$ being harvested on 
Table 1. Effect of ethephon on yield $(\mathrm{kg})$ of individual vines and percent of total crop by harvest date, and total yield $(\mathrm{kg})$ of yellow passionfruit, 1988

\begin{tabular}{|c|c|c|c|c|c|c|c|c|c|c|c|}
\hline \multirow{3}{*}{$\begin{array}{l}\text { Ethephon } \\
\text { (ppm) }\end{array}$} & \multicolumn{10}{|c|}{ Yield $(\mathrm{kg})$ and percent of harvest on given date } & \multirow{3}{*}{$\begin{array}{l}\text { Total } \\
\text { yield } \\
(\mathrm{kg})\end{array}$} \\
\hline & \multicolumn{2}{|c|}{16 Nov. } & \multicolumn{2}{|c|}{22 Nov. } & \multicolumn{2}{|c|}{28 Nov. } & \multicolumn{2}{|c|}{16 Dec. } & \multicolumn{2}{|c|}{22 Dec. } & \\
\hline & $\mathrm{kg}$ & $\%$ & $\mathrm{~kg}$ & $\%$ & $\mathrm{~kg}$ & $\%$ & $\mathrm{~kg}$ & $\%$ & $\mathrm{~kg}$ & $\%$ & \\
\hline 0 & 4.0 & 28 & 0.9 & 6 & 1.9 & 12 & 1.0 & 7 & 6.9 & 47 & 14.8 \\
\hline 150 & 5.8 & 59 & 0.6 & 7 & 1.0 & 7 & 0.4 & 4 & 3.4 & 23 & 11.2 \\
\hline 300 & 9.3 & 76 & 0.8 & 6 & 0.8 & 7 & 0.2 & 2 & 1.2 & 9 & 12.2 \\
\hline 600 & 10.4 & 83 & 1.0 & 9 & 0.5 & 4 & 0.1 & 1 & 0.4 & 3 & 12.4 \\
\hline \multicolumn{12}{|l|}{ Significance } \\
\hline Linear & $* *$ & $* *$ & NS & NS & NS & NS & $* *$ & $* *$ & $*$ & $* *$ & NS \\
\hline Quadratic & NS & * & NS & NS & NS & NS & $* *$ & NS & NS & NS & NS \\
\hline Cubic & NS & NS & NS & NS & NS & NS & NS & NS & NS & NS & NS \\
\hline
\end{tabular}

Table 2. Effect of ethephon on fruit weight, percent cull fruit, and marketable yield of yellow passionfruit, 1988.

\begin{tabular}{|c|c|c|c|}
\hline $\begin{array}{l}\text { Ethephon } \\
\text { (ppm) }\end{array}$ & $\begin{array}{c}\text { Wt/fruit } \\
\text { (g) }\end{array}$ & $\begin{array}{c}\text { Cull } \\
\text { fruit } \\
(\%)\end{array}$ & $\begin{array}{c}\text { Marketable } \\
\text { yield } \\
(\mathrm{kg})\end{array}$ \\
\hline 0 & 88.5 & 4 & 14.2 \\
\hline 150 & 76.9 & 17 & 9.3 \\
\hline 300 & 68.1 & 34 & 8.1 \\
\hline 600 & 65.4 & 41 & 7.3 \\
\hline \multicolumn{4}{|l|}{ Significance } \\
\hline Linear & ** & ** & $* *$ \\
\hline Quadratic & NS & NS & NS \\
\hline Cubic & NS & NS & NS \\
\hline
\end{tabular}

22 Dec. There were no differences among treatments in total yield harvested; however, the percent of cull fruits increased with increasing ethephon rates, thereby reducing marketable yields (Table 2). If a killing frost had occurred at the normal date, marketable yields would have been greater with the ethephon treatments. Our data suggest that ethephon treatment in the range of 150 to $300 \mathrm{ppm}$ spans the optimum for concentrating fruit harvest while resulting in the best fruit yield and lowest percentage of cull fruits among those treated.

Ethephon -treatments did not affect SSC (range $13.7 \%$ to $15.1 \%$ ) or ascorbic acid content (range 16.3 to $19.7 \mathrm{mg} / 100 \mathrm{ml}$ ) (Table 2), or the yellow color of the juice (data not shown). The SSC found in this experiment is lower than the average of $17.3 \%$ reported by Pruthi and Lae (1959) for purple passionfruit but is within the range of $13.6 \%$ to $17 \%$ for yellow passionfruit recorded by Casimir et al. (1981). Our ascorbic acid content of $16 \mathrm{mg}$ is $\approx 50 \%$ less than the 34.6 mg reported by Pruthi and Lae (1959) but is only slightly lower than the range of 17 to $32 \mathrm{mg}$ summarized by Casimir et al. (1981) for various seasons and countries. Arjona and Matta (1990) exposed purple passionfruit, which were harvested at the green mature stage (55 to 60 days after anthesis), to 10 ppm ethylene. After storage for 10 days at $10 \mathrm{C}, \mathrm{SSC}$ and $\mathrm{pH}$ of the juice did not differ between those harvested green-mature and those harvested vine-ripened (70 to 80 days after anthesis) but not treated with ethephon.

In our study, average fruit weight decreased with increasing ethephon concentration (Table 2), which reflects the increased percentage of cull fruits. Most of the cull fruits were of mature size when treated; however, the juice sacs remained white and small and did not contain any yellow juice. This lack indicates that the fruits would have to be at a certain minimum stage of development for normal fruit maturity to occur after ethephon treatment.

Yields obtained in this study are less than the reported annual yields from tropical areas where the fruit is harvested continually throughout the year. However, if the yellow passionfruit can be produced as an annual crop in temperate zone areas, and the maturity and ripening of the crop can be concentrated by ethephon treatment before the occurrence of killing frost, a viable commercial enterprise could be developed. The planting of older vines in the spring to determine the effect of plant age on earlier flowering and fruit set and the effect of ethephon treatments on the ripening of fruit of a more mature stage than. those used in the present experiment needs investigation.

\section{Literature Cited}

Arjona, H.E., F.B. Matta. 1990. Ethylene induced ripening of green mature passionfruit (Passiflora edulis, Sims). HortScience 25:1100 (Abstr.)

Buckovac, M.J., F. Zucconi, R.P. Larsen, and C.D. Kesner. 1969. Chemical promotion of fruit abscission in cherries and plums with special reference to 2-chloroethylphosphonic acid. J. Amer. Soc. Hort. Sci. 94:226-230.
Casimir, D.J., J.F. Kefford, and F.B. Whitfield. 1981. Technology and flavor chemistry of passionfruit juices and concentrates. Adv. Food Res. 27:243-295.

Edgerton, L.J. and C.D. Blanpied. 1968. Regulation of growth and fruit maturation with 2chloroethane-phosphoric acid. Nature (London) 219:1064-1065.

Ketchie, D.O. and M.W. Williams. 1970. Effect of fall application of 2-chlorcthyl-phosphoric acid on apple trees. HortScience 4:167-168.

Martin, F.W. 1984. Yellow passionfruit, p. 259260. In: F.W. Martin (cd.). CRC handbook of tropical food crops. CRC, Boca Raton, Fla.

McGregor, S.E. 1976. Passionfruit and giant granadilla, p. 278-281. In: S.E. McGregor (cd.) Insect and pollination of cultivated crop plants U.S. Dept. Agr. Hdbk. 496. Washington, D.C.

Morton, J.F. 1987. Passifloraceae, p. 320-328. In: C.F. Dowling (cd.). Fruits of warm climates. Creative Resource Syst., Inc., Winterville, N.C.

Pratt, A.K. and J.D. Goeschl. 1969. Physiological roles of ethylene in plants. Annu. Rev. Plant Physiol. 20: 541-584.

Pruthi, J.S. and G. Lae. 1959. Composition of passionfruit (Passiflora edulis, Sims.). J. Sci. Food Agr. 10:188-192.

Robinson, R.W., H. Wilezynski, F.G. Dennis, Jr., and H.H. Bryan. 1968. Chemical promotion of tomato fruit ripening. Proc. Amer. Soc. Hort. Sci. 93:823-830.

Russo, L., Jr., H.C. Dostal, and A.C. Leopold. 1968. Chemical regulation of fruit ripening. Bioscience 18:109.

Rymal, K.S. 1983. Portable micro method for quantitative determination of vitamin $\mathrm{C}$ in fruit and vegetable juices. Anal. Chem. 66:810-813.

Sims, W.L., H.B. Collins, and B.L. Gledhill. 1970. Ethrel effects on fruit ripening of peppers. Calif. Agr. 24(2):4-5.

Warner, H.L. and A.C. Leopold. 1969. Ethylene evolution from 2-chloroethyl-phosphoric acid. Plant Physiol. 44:156-158.

Williams, C.N., W.Y. Chew, and J.J. Jajaratnam. 1980. Passionfruit (Passiflora edulis), p. 133-134. In: W.A.J. Payne (cd.). Tree and field crops of the wetter regions of the tropics. Longman, New York. 